\title{
Child behavior during the social distancing in the COVID-19 pandemic
}

\author{
Comportamento infantil durante o distanciamento social na pandemia de COVID-19 \\ Conducta infantil durante el aislamiento social en la pandemia de COVID-19
}

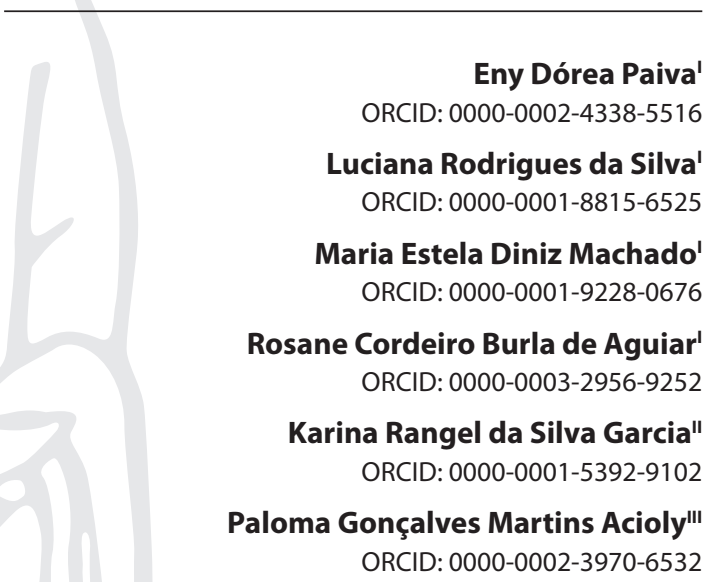

'Universidade Federal Fluminense. Niterói, Rio de Janeiro, Brazil. "Hospital Santa Izabel. Cabo Frio, Rio de Janeiro, Brazil. "II Instituto Fernandes Figueira, Fiocruz. Rio de Janeiro, Rio de janeiro, Brazil.

How to cite this article: Paiva ED, Silva LR, Machado MED, Aguiar RCB Garcia KRS, Acioly PGM. Child behavior during the social distancing in the COVID-19 pandemic. Rev Bras Enferm. 2021;74(Suppl 1):e20200762. doi: http://dx.doi.org/10.1590/0034-7167-2020-0762

Corresponding author: Eny Dórea Paiva E-mail: enydorea@gmail.com

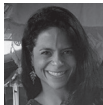

EDITOR IN CHIEF: Dulce Barbosa ASSOCIATE EDITOR: Priscilla Broca

\section{ABSTRACT}

Objective: To describe the daily activities performed by children from 6 to 12 years of age incomplete and analyze children's behavior during social distancing in the face of the COVID-19 pandemic. Methods: Cross-sectional study with children in a learning stage living in Brazil. The data were collected via online form. Fisher's exact test was applied to analyze the association of categorical variables with child behavior; when significant, it was used the odds ratio. It was considered results considered statistically significant those presenting values of $p<0.05$. Results: Data from 530 children were analyzed: $50.3 \%$ female, $71.3 \%$ from the Southeast Region, $73 \%$ in fulltime social distancing, $52 \%$ presented anxiety, which was significantly associated with changes in sleep and appetite. Conclusion: The results indicate the need for parents/caretakers to stimulate moments for the child to express themselves, not minimizing their feelings and providing emotional support to mitigate the negative impact of these feelings on the child's mental and physical health.

Descriptors: Pandemics; Social Isolation; Child Behavior; Pediatrics; Pediatric Nursing.

\section{RESUMO}

Objetivo: Descrever as atividades diárias realizadas por crianças de 6 a 12 anos incompletos e analisar o comportamento infantil durante distanciamento social diante da pandemia de COVID-19. Métodos: Estudo transversal com crianças em fase escolar, residentes no Brasil. Os dados foram coletados via formulário on-line. Para análise da associação de variáveis categóricas com comportamento infantil, aplicou-se teste exato de Fisher; quando significante, utilizou-se o odds ratio. Foram considerados resultados estatisticamente significantes valores de $p<0,05$. Resultados: Analisados dados de 530 crianças: 50,3\% do sexo feminino, 71,3\% da Região Sudeste, $73 \%$ em distanciamento social integral; $52 \%$ apresentaram ansiedade, e esta associou-se significativamente com alterações no sono e apetite. Conclusão: Os resultados apontam a necessidade de pais/responsáveis estimularem momentos para a criança se expressar, não minimizando seus sentimentos e provendo suporte emocional a fim de se atenuar o impacto negativo desses sentimentos sobre a saúde mental e física da criança. Descritores: Pandemias; Isolamento Social; Comportamento Infantil; Pediatria; Enfermagem Pediátrica.

\section{RESUMEN}

Objetivo: Describir las actividades diarias realizadas por niños de 6 a 12 años incompletos y analizar la conducta infantil durante aislamiento social frente a la pandemia de COVID-19. Métodos: Estudio transversal con niños en fase escolar, residentes en Brasil. Los datos recogidos vía formulario online. Para análisis de la relación de variables categóricas con conducta infantil, se aplicó test exacto de Fisher; cuando significante, se utilizó el odds ratio. Considerados resultados estadísticamente significantes valores de $p<0,05$. Resultados: Analizados datos de 530 niños: 50,3\% del sexo femenino, 71,3\% de la Región Sudeste, 73\% en aislamiento social integral; $52 \%$ presentaron ansiedad, y esta se relacionó significativamente con alteraciones en el sueño y apetito. Conclusión: Resultados apuntan la necesidad de padres/responsables estimularen momentos para el niño expresarse, no minimizando sus sentimientos y proveyendo suporte emocional para atenuarse el impacto negativo de esos sentimientos sobre la salud mental y física del niño.

Descriptores: Pandemias; Aislamiento Social; Conducta Infantil; Pediatría; Enfermería Pediátrica. 


\section{INTRODUCTION}

With the growth in the number of cases, deaths, and countries affected by Coronavirus Disease (COVID-19), the World Health Organization (WHO) declared on January 30, 2020, that the event constituted a Public Health Emergency of International Concern $(\mathrm{PHEIC})^{(1)}$. Soon after, with the notification of more than 110.000 cases and 4.000 deaths in many countries on all continents, on March 11, 2020, the WHO declared COVID-19 a pandemic ${ }^{(1)}$.

In Brazil, on February 6, 2020, Law №. 13,979 was sanctioned, which provides measures to face the epidemic of COVID-19(2). Among the interventions to reduce transmission, in mid-March 2020 , social distancing started with school closures ${ }^{(3)}$, keeping all children at home and part of the general population that did not work with essential services. Thus, in this context, some schools began to organize themselves to minister classes online.

It is known that the adoption of such measures has important impacts on daily activities, people's lives, and society in general. Among these routine changes, the children's population stops attending schools, having their learning interrupted, and face a new reality to which they need to adapt. The restriction of social contact can have consequences for the mental and physical health of people, particularly children and the elderly, but no study describes the behavior of children in the face of this social distancing or the adequacy of those children to the new routine, especially in the face of a pandemic ${ }^{(4-5)}$.

A study conducted in Japan during the H1N1 flu epidemic in 2009 describes children's routine during school closings and class cancellations $^{(6)}$. They report that about $80 \%$ of children stayed at home and got out only for essential reasons (e.g., going to the hospital). However, they did not report on the activities carried out at home during the period when the children did not have face-to-face classes or the effects of this distancing on behavior and, consequently, on child development ${ }^{(6)}$.

The Brazilian Society of Pediatric Nurses (BSPN) emphasizes some recommendations given the relevance of the issue and the situation that society is experiencing at this pandemic ${ }^{(7)}$. Among these recommendations, BSPN highlights the importance of family interaction with children in social distancing, who cannot attend school and carry out other activities, remaining at home in the company of parents and/or a responsible adult. The BSPN reinforces health professionals to help families to stay together, exchange affections, strengthen interactions between family members, and indicate the use of playful activities, making use of games to help face this crisis ${ }^{(7)}$.

The intermediate years of childhood or second childhood, which comprise approximately 6 to 12 years, are often called school years. These children go to school not only for socialization but also for the acquisition of knowledge in general, needing daily coexistence for the full development in all aspects of their lives. According to the Child Statute, a person up to 12 years old is considered an incomplete child ${ }^{(8)}$. For this reason, it is necessary to understand how is set up a routine of social distancing for a child in the age range of 6 to 12 years incomplete, whose space to learn, play and relate to others has been limited.

Despite the necessary social distancing to control the pandemic, it is important to stress out that it is also necessary to prevent psychosocial disorders related to this conjuncture, which at this moment, due to the emergency situation itself, are in the background. The knowledge of this routine allows health professionals to reflect on promoting actions aimed at supporting and helping children's families overcome this event never experienced before.

\section{OBJECTIVE}

Describe the routine activities performed by children from 6 to 12 years incomplete and analyze the child behavior during social distancing in the face of the COVID-19 pandemic.

\section{METHODS}

\section{Ethical Aspects}

The research was developed considering the Resolution $\mathrm{n}^{\circ}$ $466 / 2012$ of the National Council of Health/Ministry of Health and approved by the Ethics Committee of the Medical School of the Universidade Federal Fluminense (UFF).

\section{Design, period, and place of study}

Cross-sectional study, whose data collection was conducted in April 2020 through online research using the Google Forms platform, with participants from all Brazil regions.

\section{Population, sample: criteria of inclusion and exclusion}

It was a convenience sampling, and the research was distributed through the Whatsapp application, via email and Facebook, and the dissemination was restricted to family members, friends of relatives, and acquaintances of the researchers who shared the link. It was included 530 forms filled out online with complete answers by persons responsible for Brazilian children between 6- and 12-years old incomplete who live in Brazil and who sent the answers within the 24 hours established for the data collection period. Eighteen forms were excluded because the children lived outside the country.

\section{Study protocol}

The data collection instrument was a form filled out online, via Google Forms. The variables collected on the children were: region of residence, gender, age, type of school, the existence of online class or video class, recreational and physical activities, sleep, food, and behavioral data in which those responsible noted changes during social distancing.

\section{Analysis of results and statistics}

Data were tabulated using Microsoft Excel 2016 software. They were then imported into IBM-SPSS (Statistical Package for the Social Sciences), version 24, for the proper analytical treatment. Descriptive statistics were used, then arranged in table form, to count frequencies and percentages of the variables under study. After initial data evaluations, it was applied statistical methods to verify associations between the variables. The Fisher statistical test (association test) was adopted to evaluate the performance between two categorical variables; when significant, the odds ratio was applied. 


\section{RESULTS}

530 completed forms were analyzed. Table 1 shows the children' profile.

In the form, it was questioned if those responsible verified any change in child behavior. Among changes, such as agitation, aggressiveness, discouragement, irritability, and fear, anxiety was present in over $52 \%$ of children. In case those responsible had observed some other behavior different from the options, they marked "others." Among these were: impatience, need for more attention, and greater sensitivity when receiving a negative response.

Table 1 - Children's profile, Rio de Janeiro, Rio de Janeiro, Brazil 2020

\begin{tabular}{|c|c|c|}
\hline & $\mathbf{n}$ & $\%$ \\
\hline \multicolumn{3}{|c|}{ In what region do you live? } \\
\hline Midwest & 54 & 10.2 \\
\hline Northeast & 71 & 13.4 \\
\hline North & 9 & 1.7 \\
\hline Southeast & 378 & 71.3 \\
\hline South & 18 & 3.4 \\
\hline \multicolumn{3}{|c|}{$\begin{array}{l}\text { Are you or another person responsible for the child } \\
\text { in fulltime social isolation? }\end{array}$} \\
\hline No & 143 & 27.0 \\
\hline Yes & 387 & 73.0 \\
\hline \multicolumn{3}{|c|}{ What is the child's gender? } \\
\hline Female & 266 & 50.3 \\
\hline Male & 263 & 49.7 \\
\hline \multicolumn{3}{|l|}{ What is the child's age? } \\
\hline $6-7$ & 175 & 33.2 \\
\hline $8-9$ & 179 & 33.9 \\
\hline 10-12 incomplete & 173 & 32.8 \\
\hline \multicolumn{3}{|c|}{ Is the child in fulltime social distancing? } \\
\hline No & 147 & 27.7 \\
\hline Yes & 383 & 72.3 \\
\hline \multicolumn{3}{|c|}{ In what type of school does the child study? } \\
\hline Privada & 473 & 89.2 \\
\hline Pública & 57 & 10.8 \\
\hline \multicolumn{3}{|c|}{ Is the child taking an online class or video lesson? } \\
\hline No & 84 & 15.8 \\
\hline Yes & 446 & 84.2 \\
\hline \multicolumn{3}{|c|}{$\begin{array}{l}\text { Does the child have a routine with established } \\
\text { schedules for study and playtime? }\end{array}$} \\
\hline No & 122 & 23.0 \\
\hline Yes & 408 & 77.0 \\
\hline \multicolumn{3}{|c|}{$\begin{array}{l}\text { Did you notice any different behavior in the child } \\
\text { during social distancing? }\end{array}$} \\
\hline \multicolumn{3}{|c|}{ Agitation } \\
\hline No & 341 & 64.3 \\
\hline Yes & 189 & 35.7 \\
\hline \multicolumn{3}{|l|}{ Agressiveness } \\
\hline No & 437 & 82.5 \\
\hline Yes & 93 & 17.5 \\
\hline \multicolumn{3}{|l|}{ Anxiety } \\
\hline No & 253 & 47.7 \\
\hline Yes & 277 & 52.3 \\
\hline \multicolumn{3}{|l|}{ Discouragement } \\
\hline No & 413 & 77.9 \\
\hline Yes & 117 & 22.1 \\
\hline \multicolumn{3}{|l|}{ Irritability } \\
\hline No & 308 & 58.1 \\
\hline Yes & 222 & 41.9 \\
\hline \multicolumn{3}{|l|}{ Fear } \\
\hline No & 407 & 76.8 \\
\hline Yes & 123 & 23.2 \\
\hline \multicolumn{3}{|l|}{ Others } \\
\hline No & 485 & 91.5 \\
\hline Yes & 45 & 8.5 \\
\hline
\end{tabular}

Table 2 shows the results between recreational and physical activities of children according to the presence of anxiety. It was not possible to detect statistical differences in the characteristics analyzed. It should be noted that the comparison of physical activity performance is within the limits of significance. Therefore, if there is flexibility in the level of significance (e.g., for 10\%), one can consider the existence of evidence that children who do not engage in physical activity have 1.37 times more chance of being anxious when compared to those who perform physical activity $(p=0.079)$.

It is important to emphasize that the entertainment activities carried out with the children during the period of fulltime social distancing were the use of cell phones, tablets, computers, and television. They were also watching movies with the family, reading, playing board games, activities that include painting, games, masses, puzzles, music, gymkhanas, and other types of games. They were cooking with people responsible for them, talking more, praying and reading the Bible, stimulating participation in domestic activities, taking care of family pets.

Table 2 - Comparison between physical and recreational activities according to the presence of anxiety - Rio de Janeiro, RJ, Brazil 2020

\begin{tabular}{|c|c|c|c|c|c|c|}
\hline & \multicolumn{4}{|c|}{ Anxiety } & \multirow{3}{*}{$\underset{\text { value* }}{p}$} & \multirow{3}{*}{$\begin{array}{c}\mathrm{OR}^{\dagger} \\
(\mathrm{Cl} \text { of 95\%) }\end{array}$} \\
\hline & \multicolumn{2}{|c|}{ No } & \multicolumn{2}{|c|}{ Yes } & & \\
\hline & $\mathbf{n}$ & $\%$ & $\mathbf{n}$ & $\%$ & & \\
\hline $\begin{array}{l}\text { Does the child perform } \\
\text { any type of physical }\end{array}$ & & & & & & \\
\hline $\begin{array}{l}\text { activity at home } \\
\text { during full time social } \\
\text { distancing? }\end{array}$ & & & & & 0.079 & \\
\hline No & 134 & 44.4 & 168 & 55.6 & & 1.37 (0.97-1.93) \\
\hline Yes & 119 & 52.2 & 109 & 47.8 & & (Ref) \\
\hline \multicolumn{7}{|l|}{$\begin{array}{l}\text { What is being done } \\
\text { to entertain the child } \\
\text { during full time social } \\
\text { distancing? }\end{array}$} \\
\hline $\begin{array}{l}\text { Cell phone, tablet, } \\
\text { computer, television }\end{array}$ & & & & & 0.148 & \\
\hline No & 12 & 66.7 & 6 & 33.3 & & \\
\hline Yes & 241 & 47.1 & 271 & 52.9 & & \\
\hline $\begin{array}{l}\text { Watching movies } \\
\text { with the family }\end{array}$ & & & & & 0.054 & \\
\hline No & 54 & 56.8 & 41 & 43.2 & & \\
\hline Yes & 199 & 45.7 & 236 & 54.3 & & \\
\hline Reading & & & & & 0.789 & \\
\hline No & 96 & 46.8 & 109 & 53.2 & & \\
\hline Yes & 157 & 48.3 & 168 & 51.7 & & \\
\hline Playful activities & & & & & 0.654 & \\
\hline No & 162 & 48.5 & 172 & 51.5 & & \\
\hline Yes & 91 & 46.4 & 105 & 53.6 & & \\
\hline Board games & & & & & 0.662 & \\
\hline No & 110 & 46.6 & 126 & 53.4 & & \\
\hline Yes & 143 & 48.6 & 151 & 51.4 & & \\
\hline Others & & & & & 0.859 & \\
\hline No & 154 & 48.1 & 166 & 51.9 & & \\
\hline Yes & 99 & 47.1 & 111 & 52.9 & & \\
\hline
\end{tabular}

However, in Table 3, there are comparisons between the impact of anxiety on children's sleep and appetite. It is important to highlight that the children characterized as having an alteration in sleep had increased or decreased sleep, agitation, or nightmares. The change in appetite was characterized by an increase or decrease in appetite during social distancing. It was possible to detect effects on the child's sleep ( $p<0.001)$. Therefore, children with anxiety are 2.12 times more likely to have alterations in sleep than those 
without anxiety. Similarly, anxiety is associated with appetite ( $\mathrm{p}$ $<0.001)$. Therefore, anxious children are 3.12 times more likely to have appetite changes than those who do not have this disorder.

Table 3 - Comparison between sleep and appetite alterations according to the presence of anxiety - Rio de Janeiro, Rio de Janeiro, Brazil 2020

\begin{tabular}{|c|c|c|c|c|c|c|}
\hline & & Anx & kiety & & & \\
\hline & $\mathbf{N}$ & Jo & $Y_{5}$ & es & $p$ & $\mathbf{O R}^{\dagger}$ \\
\hline & $\mathbf{n}$ & $\%$ & $\mathbf{n}$ & $\%$ & & \\
\hline $\begin{array}{l}\text { Did the child have any } \\
\text { sleep changes during the } \\
\text { social distancing? }\end{array}$ & & & & & $<0.001$ & \\
\hline No & 138 & 54.5 & 100 & 36.1 & & (Ref) \\
\hline Yes & 115 & 45.5 & 177 & 63.9 & & $2.12(1.50-3.00)$ \\
\hline $\begin{array}{l}\text { Did the child have a change } \\
\text { in his or her appetite during } \\
\text { social distancing? }\end{array}$ & & & & & $<0.001$ & \\
\hline No & 152 & 60.1 & 90 & 32.5 & & (Ref) \\
\hline Yes & 101 & 39.9 & 187 & 67.5 & & $3.12(2.19-4.46)$ \\
\hline
\end{tabular}

The presence of the children at home generated a need to reorganize the family dynamics for this unprecedented moment because the families needed to adapt to have the presence of someone responsible for their care. In this sample, the majority (73\%) of those people responsible remained confined together with the children, and $77 \%$ reported that they introduced a routine of studies and games for them.

In this context, there has been a change in the children's routine, as they have suddenly been impeded from going to school, performing their sports activities, playing with their friends, visiting their families, among other types of socialization. Besides, they may have been affected by the financial difficulties experienced by their families (e.g., family members or caregivers who lost their jobs or had their income reduced) and also by the illness, hospitalization, or death of close relatives, which may have implications for their sense of security and normality ${ }^{(9)}$.

Some authors prepared a brochure that presented aspects related to mental health and psychosocial care of children in the pandemic context. They highlight factors related to work overload, the family environment's demands, and the weakening of the support networks' functioning. Those authors state that planning the day and keeping it as close as possible to the usual routine can be a protective factor against the emergence of anxiety and stress symptoms ${ }^{(9)}$.

Maintaining the routine helps the children to keep their stability and balance. To all of them, playing is their favorite activity, regardless of their environment. Through playing, the child acquires knowledge and increases interaction with people, thus improving ways of dealing with their expectations and frustrations, learning to live together in a group, and to expose their feelings ${ }^{(10)}$.

Although $84 \%$ of the children in this study were having some online class or video lesson, in children and adolescents, the stress of the pandemic generated by the interruption of pedagogical activities, the disorganization of family and social coexistence, the interruption of team sports and, often, the difficulty of those responsible for meeting emotional needs can contribute to the emergence of psychological suffering, such as insomnia, anorexia, anxiety crises or depression ${ }^{(11)}$.

Anxiety is the expectation of an imagined or potential threat at any level; it is usually vague and unfocused and can affect emotions, thinking processes, body sensations, and behaviors ${ }^{(12)}$. In this study, those responsible for children reported that $52 \%$ presented anxiety, with no statistical difference between ages. The Brazilian Society of Pediatrics (BSP) points out that severe psychological traumas appear when situations out of the order of ordinary life experiences overcome the individual's mental elaboration capacity, leaving marks on mind and body ${ }^{(13)}$.

Irritability and agitation were also behavioral alterations commonly presented by children in this study during the pandemic. These and other changes in behavior are expected, given the circumstances experienced at this time. However, it is important to be aware of their emergence in order to prevent more severe consequences. For meeting each child's demands, it is essential to understand this situation to understand that they are adaptive reactions, resulting from the social distancing related to the pandemic of COVID-19, and are not pathological. Children's behavior alterations need to be addressed collectively and should be followed up after the end of the social distancing to use resources to minimize them ${ }^{(9,11)}$.

In the face of the installed pandemic, the support of families is crucial in preventing damage to the children's health and development. Because it is an adverse situation, daily stress is high. It can be toxic, given the physiological response of elevation of stress hormones in childhood, such as cortisol and adrenaline, with consequences of overloading the cardiovascular system and risks to the brain architecture's healthy construction. In the short term, stress can have several developments, such as sleep disorders, irritability, worsening of immunity, fears. In the medium and long term, higher prevalence of developmental delays, anxiety disorders, depression, drop in school performance, and an unhealthy lifestyle in adult life. Thus, the application of evidence-based practices can contribute to the preservation of our children's well-being ${ }^{(14)}$.

In this sense, for good mental health, the WHO recommends: keeping the family routine; talking openly and honestly about the new coronavirus with children, using language that is accessible according to their age; showing the child that he or she can also learn at home; reserving time for play; helping children find positive ways to express feelings such as fear and sadness ${ }^{(15)}$.

Authors emphasize the need for mental health professionals to establish evidence-based guidelines and more straightforward operational strategies for dealing with COVID-19 pandemic-related mental health problems in children, improving access to mental health services, and monitoring post-pandemic mental disorder in children ${ }^{(16)}$. Professionals must use technical and scientific knowledge for children's families in order to promote actions that transform reality in order to empower them ${ }^{(16)}$, improving their quality of life.

The social distancing brought changes to the entire world population. The closing of schools and establishments and the restriction to circulate in the streets even for walking and exercise practices have been interfering, without a doubt, in the adaptation of the child population for a projection of quality of life and physical well-being. Physical activity at home during 
social distancing was a factor that reduced the possibility of the child to develop anxiety. This study shows that children who did not practice physical activities have 1.37 times more chance to develop anxiety than those who performed physical activity.

The school environment provides physical fitness development through the already established curriculum and with its extracurricular projects such as ballet, soccer, and volleyball classes, among others. However, with home confinement and the closure of services that are not considered essential, children do not perform these physical activities. It is important to highlight that the BSPN suggests the inclusion of regular physical activity at home since several gyms and professionals have offered free online classes, as well as the adoption of practices that promote physical and mental well-being, such as yoga and meditation. They recommend interspersed periods of physical activities within the home in more than one hour of the day, in the morning and afternoon shifts, and, if possible, parents and children should perform the activities together. Also, they suggest stimulating the child to be creative to perform these activities at home, through circuits made with pillows and plastic bottles, skipping rope, dancing, practicing martial arts, among others ${ }^{(7)}$.

As for the recreational activities the children perform, those respondents reported that they use screens (cell phone, tablet, computer, and/or television), watch movies with the family, read and develop playful activities, and play board games. There was no significant statistical difference in the frequency of those activities among the children who participated in this study. There was also no activity that they did more; however, more than $80 \%$ of those in charge reported that the children increased the use of screens in this period.

In this sense, the orientation of the Brazilian Society of Pediatrics (SBP), published in the Manual "Menos tela e mais saúde" (free translation "Less Screen and More Health"), prepared by the Grupo de Trabalho Saúde na Era Digital (free translation Working Group Health in the Digital Era) of December 2019, is that children between 6 and 10 years old should have limited the screen time to a maximum of 1-2 hours/day, always with parental/guardian supervision. Teenagers between the ages of 11 and 18 should have limited screen time and video gameplay to 2-3 hours/day, and never let them "spend the night" playing. Experts advise those responsible not to allow children and teenagers to be isolated in rooms with television, computer, tablet, cell phone, smartphones, or webcam: the use should occur in familiar places in the house. For all ages, they recommend not to use screens during meals and disconnect them 1-2 hours before bed. Families should create healthy rules for the use of digital equipment and applications, in addition to security rules, passwords, and filters appropriate for the child ${ }^{(11)}$.

It is essential to use technology to everyone's advantage. According to SBP's recommendations, besides defining with children the schedules for the healthy use of screens, avoiding to exceed the limits and unattended access to inappropriate content, establishing schedules for online games with friends, it is important to stimulate videoconferences with grandparents, family, and friends, encouraging cheerful conversations and moments of relaxation during distance contacts ${ }^{(14)}$. At home, when away from home, parents are usually the best and closest resource for their children to seek help.
Besides communication between those in charge and the children, it is essential to include them in domestic chores, respecting the abilities according to age. Encouraging them to perform these domestic activities in a joyful and pleasurable way can bring them great learning. Furthermore, caregivers can talk to them to respect the moments when adults need to work in a more concentrated way, trying to synchronize the time of that need by showing a movie or doing some activity in which children do not need so much supervision ${ }^{(9)}$.

Sleeping habits, which are influenced by biological, psychological, environmental, family, and socio-cultural factors, should also be included in the routine activities important for childhood growth and development ${ }^{(13)}$. The present research findings indicate that more than half of the children had some change in their sleep pattern during the period of social distancing. These changes reported by family members are in line with the BSP when it states that adverse situations such as social isolation can increase stress hormone levels in childhood, such as cortisol and adrenaline, and this can generate several short-term consequences, such as sleep disorders, irritability, worsening of immunity and fears ${ }^{(13)}$.

Among the emotional reactions and behavioral changes often presented by children during the pandemic, the following stand out: concentration difficulties, irritability, fear, restlessness, boredom, feeling lonely, sleep pattern changes, and eating. In general terms, these manifestations are expected in the face of the adversities of the current scenario. Dealing with these emotional reactions and behavioral changes is not always easy for family members or caregivers, who also tend to report higher stress and anxiety levels during this period ${ }^{(9)}$.

There is a consensual public health concern regarding the risk of childhood obesity in all age groups ${ }^{(18-19)}$. One of the main factors leading to this is the sedentariness due to body inactivity. With a decrease in physical activity without a decrease in the amount of food ingested, the change in lifestyle makes the child susceptible to the risk of overweight ${ }^{(18)}$.

In this study, the data showed that anxious children are 3.12 times more likely to have appetite changes than those who do not have this disorder. The eating habit is always linked to a cultural and social context experienced by each family group. People do not eat to satisfy physiological needs but also to satisfy some emotional need, and that is why external factors influence so much the quality of life and obesity ${ }^{(20)}$.

At the same time, there is evidence that changes in eating habits and daily activities are considered the main responsible factors for the increased incidence of obesity. It is perceived that several factors influence human behavior, and these are remarkable, especially when there is a change in routine and a decrease in physical activity ${ }^{(21)}$.

However, the eating habits follow the family reference, making the cause even more worrisome about the change in the child's appetite during social distancing. The importance of those responsible for establishing eating schedules was observed, offering and stimulating the ingestion of fruits, vegetables, leaves, and tuber, decreasing the supply of food rich in sugars and fats ${ }^{(22)}$. Although the sample of this study revealed that many children increased their food intake, some children had their appetite reduced.

In light of all this change in the world and people's routines, the authors highlight the need for mental health professionals to 
establish evidence-based guidelines and more straightforward operational strategies for dealing with COVID-19 pandemicrelated mental health problems in children, improving access to mental health services, and monitoring post-pandemic mental disorder in children ${ }^{(16)}$.

\section{Study limitations}

A limitation of the study was the convenience sampling because it may not represent the entire Brazilian child population from 6 to 12 years old.

\section{Contributions to the fields of Nursing, Health or Public Policy}

The study contributes by emphasizing the repercussions of the social distancing generated by the COVID-19 pandemic on children's health, showing changes in behavior that can be perceived by parents/guardians in daily care. Also, in this work, it was indicated to health professionals, especially those who work with the children and their families, the importance of guiding parents/guardians regarding the need to be emotional support, a support network for children, highlighting the relevance of observation, stimulation to play so that they can express themselves freely, talking about the disease, about the loss of people close or known to them.
Besides, it was pointed out the need for these professionals to monitor child behavior for possible mental disorders during and after the pandemic period.

\section{CONCLUSION}

This study described the routine and analyzed data of children between 6 and 12 years old incomplete during the COVID-19 pandemic. The results showed that most of them remained in fulltime social distancing, together with those responsible for them, who reported having introduced a routine of studies (online classes and video classes) and games for children (cell phone, tablet, computer and/or television, movies, readings, play activities and board games).

Nevertheless, anxiety was described by most of those responsible and significantly associated with changes in sleep and appetite when compared to children who did not present the disorder. There were also indications that children who did not practice physical activities were more likely to have anxiety. These results point to parents/guardians' need to recognize the signs of changes in children's behavior. They should stimulate moments to express themselves, not minimize their feelings, and provide emotional support to mitigate the negative impact of these feelings on the child's mental and physical health at this time of social distancing. In the post-pandemic period, the movement to return to daily activities may also generate insecurity and expectation, contributing to an increase in anxiety.

\section{REFERENCES}

1. World Health Organization (WHO). Statement on the second meeting of the International Health Regulations (2005). Emergency Committee regarding the outbreak of novel coronavirus (2019-nCoV) [Internet]. Geneva: World Health Organization; 2020 [cited 2020 Apr 16]. Available from: https://www.who.int/news-room/detail/30-01-2020-statement-on-the-second-meetingof-the-international-healthregulations-(2005)-emergency-committee-regarding-the-outbreak-of-novel-coronavirus-(2019-ncov)

2. Presidência da República (BR). Lei № 13.979 de 6 de fevereiro de 2020. Dispõe sobre as medidas para enfrentamento da emergência de saúde pública de importância internacional decorrente do coronavírus responsável pelo surto de 2019 [Internet]. 2020[cited 2020 Apr 16]. Available from: http://www.planalto.gov.br/ccivil_03/_ato2019-2022/2020/lei/L13979.htm

3. Presidência da República (BR). Medida Provisória № 934, de $1^{\circ}$ de abril de 2020. Estabelece normas excepcionais sobre o ano letivo da educação básica e do ensino superior decorrentes das medidas para enfrentamento da situação de emergência de saúde pública de que trata a Lei no 13.979, de 6 de fevereiro de 2020 [Internet]. 2020[cited 2020 Apr 16] Available from: https://www.in.gov.br/en/web/dou/-/ medida-provisoria-n-934-de-1-de-abril-de-2020-250710591

4. Anderson RM, Heesterbeek H, Hollingsworth TD. How will country-based mitigation measures influence the course of the COVID-19 epidemic? Lancet. 2020;395(10228):931-4. https://doi.org/10.1016/S0140-6736(20)30567-5

5. Armitage R, Nellums LB. COVID-19 and the consequences of isolating the elderly. Lancet Public Health. 2020;pii:S2468-2667(20)30061-X. https://doi.org/10.1016/S2468-2667(20)30061-X

6. Mizumoto K, Yamamoto T, Nishiura H. Contact behaviour of children and parental employment behaviour during school closures against the pandemic influenza A (H1N1-2009) in Japan. J Int Med Res. 2020;716-24. https://doi.org/10.1177/0300060513478061

7. Sociedade Brasileira de Enfermeiros Pediatras-SOBEP. Materiais Informativos sobre a COVID-19: recomendações da Sociedade Brasileira de Enfermeiros Pediatras em tempos de Coronavírus (COVID-19) [Internet]. 2020[cited 2020 Apr 22]. Available from: https://sobep.org.br/ conteudo/orientacao-covid-29/

8. Presidência da República (BR). Lei n 8.069, de 13 de julho de 1990. Dispõe sobre o Estatuto da Criança e do Adolescente e dá outras providências [Internet]. 1990[cited 2020 Set 28]. Available from: http://www.planalto.gov.br/ccivil_03/leis/l8069.htm

9. Fundação Oswaldo Cruz (FioCruz). Saúde Mental e Atenção Psicossocial na Pandemia Covid-19: crianças na pandemia covid-19 [Internet]. 2020. [cited 2020 Apr 22]. Available from: https://www.fiocruzbrasilia.fiocruz.br/ criancas-e-pandemia-como-abordar-as-reacoes-emocionais-e-comportamentais/

10. Bispo CCL, Bispo LB, Oscar BSL. Inventário dos jogos e brincadeiras: a manifestação da cultura lúdica infantil. Diversitas J [Internet]. 2020[cited 2020 Apr 22];5(1):500-22. Available from: https://periodicos.ifal.edu.br/diversitas_journal/article/view/1040 
11. Sociedade Brasileira de Pediatria (SBP). Manual de Orientação. Grupo de Trabalho Saúde na Era Digital (2019-2021) [Internet]. 2020[cited 2020 Apr 22]. Available from: https://www.sbp.com.br/fileadmin/user_upload/_22246c-ManOrient___MenosTelas_MaisSaude.pdf

12. Elsevier Clinical Skills. Anxiety Management (Ambulatory) - CE [Internet]. 2020. [cited 2020 Apr 22]. Available from: https://www.elsevier. com/_data/assets/pdf_file/0006/991293/Anxiety-Management-Skill-Ambulatory-COVID-19-toolkit_011220.pdf

13. Sociedade Brasileira de pediatria (SBP). Pais e filhos em confinamento durante a pandemia de COVID-19. Nota de alerta [Internet]. 2020[cited 2020 Apr 22]. Available from: https://www.sbp.com.br/fileadmin/user_upload/22420c-NAlerta_Pais_e_Filhos_em_ confinamento_COVID-19.pdf

14. Sócias CO, Brage LB, Nevot-Caldentey L. Family support against covid-19. Scielo Preprint. 2020. https://doi.org/10.1590/SciELOPreprints.297

15. World Health Organization (WHO). Looking after our mental health[Internet]. Geneva: World Health Organization; 2020. [cited 2020 Apr 16]. Available from: https://www.who.int/news-room/campaigns/connecting-the-world-to-combat- coronavirus/healthyathome/ healthyathome---mental-health

16. Liu JJ, Bao Y, Huang X. Mental health considerations for children quarantined because of COVID-19. Lancet Child Adolesc Health [Internet]. 2020[cited 2020 May 20] Available from: https://www.thelancet.com/pdfs/journals/lanchi/PIIS2352-4642(20)30096-1.pdf

17. Christoffel MM, Gomes ALM, Souza TV, Ciuffo LL. Children's (in)visibility in social vulnerability and the impact of the novel coronavirus (COVID-19). Rev Bras Enferm. 2020;3(Suppl-2):e20200302. https://doi.org/10.1590/0034-7167-2020-0302

18. Rossi CE, Costa LCF, Machado MS, Andrade DF, Vasconcelos FAG. Factors associated with food consumption in schools and overweight/ obesity in 7 to 10-year-old schoolchildren in the state of Santa Catarina, Brazil. Ciênc Saúde Coletiva. 2019;24(2):443-54. https://doi. org/10.1590/1413-81232018242.34942016

19. Linhares FMM, Sousa KMO, Martins ENX, Barreto CCM. Childhood obesity: influence of parents on nutrition and lifestyle of children. Temas Saúde[Internet]. 2016 [cited 2020 Sep 24];16(2):460-81. Available from: http://temasemsaude.com/wp-content/uploads/2016/08/16226.pdf

20. UNICEF. The State of the World's Children 2019. Children, Food and Nutrition: growing well in a changing world. [Internet]. UNICEF, New York, 2019[cited 2020 Apr 16]. Available from: https://www.unicef.org/media/63016/file/SOWC-2019.pdf

21. Ataey A, Jafarvand E, Adham D. Moradi-Asl E. The relationship between obesity, overweight, and the human development index in World Health Organization Eastern Mediterranean Region Countries. J Prev Med Public Health 2020;53(2):98-105. https://doi.org/10.3961/ jpmph.19.100

22. Souza MG, Flores RRR, Soares PDF, Soares LJF, Monteiro PA, Alves AMJT, et al. Avaliação nutricional e dietética de pré-escolares de Montes Claros, Minas Gerais. J Health NPEPS. 2019;4(1):166-81. https://doi.org/10.30681/252610103339 